\title{
A community of inquiry-based framework for civic education at Universitas Terbuka, Indonesia
}

\section{Made Yudhi Setiani \& Allan M. MacKinnon}

To cite this article: Made Yudhi Setiani \& Allan M. MacKinnon (2015) A community of inquirybased framework for civic education at Universitas Terbuka, Indonesia, Distance Education, 36:3, 351-363, DOI: 10.1080/01587919.2015.1081740

To link to this article: http://dx.doi.org/10.1080/01587919.2015.1081740

Published online: 07 Oct 2015.

Submit your article to this journal $\sqsubset$

Џ Article views: 152

Q View related articles $\llbracket$

View Crossmark data ¿ 


\title{
A community of inquiry-based framework for civic education at Universitas Terbuka, Indonesia
}

\author{
Made Yudhi Setiani ${ }^{\mathrm{a}}$ and Allan M. MacKinnon ${ }^{\mathrm{b} *}$ \\ ${ }^{a}$ Government Science Study Program, Faculty of Social and Political Sciences, Universitas \\ Terbuka, Tangerang Selatan, Banten, Indonesia; ${ }^{b}$ Faculty of Education, Simon Fraser \\ University, Canada
}

(Received 25 January 2015; final version received 6 August 2015)

\begin{abstract}
This study focused on the civic education course at Universitas Terbuka (UT). Its purpose was to design a new approach for the online tutorial for the course by analyzing the literature related to online and distance education and investigating participant feedback on the current offering of the course and tutorial, which is a compulsory course in all programs at UT. The study draws from the community of inquiry framework, which promotes a social constructivist approach as well as teaching about democracy by example. This model is intended to create meaningful learning experiences for students in a reformulated civic education course, in which they would learn to think critically through interacting with classmates, experiencing collaborative learning, and supporting fellow students in learning activities and processes. In this model, learning is seen as occurring within the community through the interaction of social presence, cognitive presence, and teaching presence where, students are able to develop civic competences, namely civic knowledge, civic skills, and civic dispositions, as well as experience a democratic interaction that forms the core of civic interactions in a democratic society.
\end{abstract}

Keywords: civic competence; civic education; community of inquiry; democracy; online learning; social constructivism

\section{Introduction}

Civic education is a compulsory course from primary to post-secondary schools in Indonesia. Civic education courses have been taught in all levels of schooling in Indonesia for decades. However, there have been indications from students that civic education courses are uninteresting and that students have not really been engaged with these courses (Zuriah, 2011). This could be caused by the teachers' approach in delivering the course, which usually draws heavily from a transmission model, or what Freire (2000) referred to as a "banking method." In this method, students only receive and store the information from the teachers. They might not have opportunities for, or are afraid to ask for, a discussion with teachers. Thus, students lack motivation to learn.

*Corresponding author. Email: amackinn@sfu.ca

An earlier version of this article was presented at the 28th Annual Conference of Asian Association of Open Universities, Hong Kong, SAR, China, 28-31 October 2014. 
The goals of civic education are to create citizens with civic competences, namely civic knowledge, skills, and dispositions. Teaching civic education requires specific teaching strategies and perspectives on learning. Print and Smith (2000) reported that considerable research demonstrates that traditional expository strategies are frequently ineffective in teaching civic education (e.g., Dynneson, 1992; Patrick $\&$ Hoge, 1991; Sears, 1994) and argued that in order to achieve a democratic, civil society, teachers require an array of pedagogical strategies that address civic education in a constructive manner.

This study examined the civic education course at Indonesia Open University or Universitas Terbuka (UT). UT is a state university and the only higher education institution in Indonesia that teaches almost entirely using a distance education format, with printed materials as the primary learning resources. In addition to printed learning materials, UT also provides learning supports in the form of tutorials, either face-to-face or online.

The online civic education tutorial at UT primarily emphasizes civic knowledge. We believed that the pedagogical approach of the online civic education tutorial needed to be refined in order to support the development of civic skills and civic dispositions. This study set out to assess the current tutorial and review the research literature to inform the development of a new online civic education tutorial for the course. The current practice of the existing online civic education tutorial at UT was analyzed based on interviews with students, tutors, and administrators who were involved in the tutorial. The proposed redesign of the course draws from the community of inquiry framework (Garrison, Anderson, \& Archer, 2000) and social constructivism, to offer a model of teaching about democracy that would also address and develop civic knowledge, skills, and dispositions. The idea, as it has unfolded in our review of the literature regarding best practices, is to create a virtual world in the online environment that represents the students' development of civic knowledge, civic identity, voice, and agency. Therefore, the tutorial is to mirror the interaction between citizens comprising societies in the democratic world, such as learning how to interact with fellow citizens with tolerance and respect. With this model as a pedagogical approach in the civic education course, UT students would, in principle, have a meaningful educational experience of democratic engagement.

\section{The nature and role of civic education in Indonesia}

Indonesia is a fairly young democratic country with diverse cultures, ethnicities, races, and religions that represent a plurality of ways of life, views, opinions, and practices. With these differences, social conflict will easily occur if there is a lack of tolerance and respect in community relationships. People in Indonesia must be able to accept the differences among themselves to maintain a harmonious society. Tolerance, respect, and willingness to learn from each other are the values on which democratic nations thrive. These are the values that schools must teach and practice (Gerzon, 1997), and this provides both the practical context and a compelling rationale for reforming the civic education course at UT.

There are two common perceptions of democracy that are mutually interdependent: one is democracy as a form of government; the other is democracy as a philosophy for and the basis of a way of living. Print, Ornstrom, and Skovgaard Nielsen (2002) stated that democracy as a form of government is characterized by free and fair elections, division and separation of powers, the rule of law, human 
rights, freedom of speech, and so on. Meanwhile, democracy as a way of living is concerned with willingness to compromise, show tolerance, a willingness to listen to and be influenced by arguments, maintaining a civil society, acceptance of other attitudes and opinions, trust, and so forth. Essentially, this perspective is based upon those values that allow a democracy to function effectively and engage citizens.

Those two perceptions support each other. Without a legal and institutional framework a democratic lifestyle cannot effectively exist, and the converse is also true. For an effective education for democratic citizenship, the two perceptions are considered necessary and important. Successful democracies are mostly based on the values of democratic lifestyle, and democratic teaching tries to develop those values while, in the process, modeling democratic ideals and ways of being (Print et al., 2002).

Educational settings like schools offer a natural environment for learning about democracy. In such educational settings learners should be respected for their abilities and given opportunities to develop their potential, requiring an open atmosphere of trust and mutual respect in teaching and learning processes. Teaching about democracy entails sharing power in the classroom (Mattern, 1997), offering students real choices about course content and processes. According to Mattern (1997), democratic education is necessary because it better enables the development of democratic skills and dispositions. If students engage routinely in educational practices that allow them to be passive, they internalize these traits and accept them as normal. Alternatively, teaching critical intelligence, creative problem-solving skills, and adopting a critical stance toward social norms requires educational practices that develop these traits in the classroom. Democratic theory might be more readily learned and understood by practicing democracy within a program of studies (Hahn, 1998; Soder, 1996).

The goal of civic education is for every citizen to be a good citizen, a citizen who has intelligence - intellectual, emotional, social, and spiritual - has a sense of pride and responsibility, and is able to participate in the life of society and country, in order to grow a sense of nationality and patriotism (Wahab \& Sapriya, 2011). Educating people to be good citizens who have good character and who are responsible, active, and dedicated to humanity, their country, and their fellow human beings is one of the fundamental goals of a nation. The development and progress of a nation depends on the quality of its citizens. To fulfill this civic responsibility, many countries have civic education programs to educate their young as well as adult citizens.

Cogan (1998) described civic education as "the contribution of education to the development of those characteristics of being a citizen" (p. 13). From country to country, the practice of civic education varies, with most countries not treating it as a separate school subject. Civic education mostly has been locally contextualized and taught as an element of subjects such as geography, history, social studies, and moral and religious values (Kalidjernih, 2005). For Indonesia, civic education is treated as a separate school subject, and it is a compulsory subject in all levels of schooling.

The character of civic education in Indonesia's schools is based on the Indonesia State's ideology and constitution-Pancasila and the 1945 Constitution. Pancasila is the foundation of the state of Indonesia, that consist of five principles, namely, belief in the one true God, just and civilized humanity, the unity of Indonesia, democracy guided by the wisdom of representative deliberation, and social justice 
for all Indonesians. The civic education curriculum at the university level is oriented toward democracy, human rights, rule of law, and civil society. This curriculum was designed to improve students' understanding of and commitment to these issues and as such, improve the quality of their participation in Indonesia's democracy and enhance their civic knowledge, skills and disposition (Jackson \& Bahrissalim, 2007). Moreover, the basic competencies of civic education at the university level are for students to become professionals (in all fields) who have a sense of nationhood and love of the country; who are democratic and civilized; who become citizens who have a sense of disciplined agency and who actively participate in building a peaceful life based on the value system of Pancasila (see Mikhael, Sihotang, Sutrisno, Soegito, \& Heru, 2011).

\section{Online civic education at Universitas Terbuka}

At UT, the civic education course is a core course required for all students from all faculties. In addition to using the printed material as the primary learning resource, the civic education course is supported by an online tutorial to assist students in developing a deeper understanding of the course materials. The number of students who register for the course is usually large, about 3000 students, even though they are divided into several online tutorial classes, each consisting of about 200 students.

The current online tutorial uses a Moodle platform as its learning management system (LMS) and runs for 8 weeks. The tutorial includes initiations, discussions, and assignments. Initiations provide a course overview and the required learning materials for the modules. Discussion topics provide students with activities to master the content of the course. Meanwhile, assignments are provided to evaluate students' mastery of the material at weeks 3,5 and 7 (Andriani, 2013).

The online civic education course is ideal for developing the democratic ideals of tolerance and respect as behaviors that can be learned, practiced, and expected of participants in the discussion forums. Developing a respectful sense of community within the online civic education course would require tutors to model good civic dispositions and students to become aware that, through practice, they are learning to model good civic dispositions themselves, through their interactions with one another. Yet, there are many challenges that would need to be taken into consideration to bring this model to life at UT. In our research, we are seeking to develop an ideal notion of what we would like to see in the online civic education, adult learners, and online pedagogies, together with an appropriate pedagogical approach.

\section{Research methodology}

This study was largely based on the review of the literature, supported by an analysis of primary data collected from interviews with seven UT students who have taken the online civic education tutorial, and six tutors of the civic education course. Students were interviewed in focus groups, and the tutors were interviewed in individual interviews. The interviews with students and tutors were designed to gather information about their experiences and opinions on the existing practice of the online civic education tutorial at UT. The data gathered from the interviews serve to 
complement the analysis of the literature review and illustrate certain parts of the arguments for using the community of inquiry framework in the design of the online civic education tutorial at UT. Interviews with students, tutors and administrators revealed that, while participants understood the purpose of civic education and expressed no disagreement with the idea of having a compulsory course from primary to post-secondary education, many felt that the course could be improved (Setiani, 2014). Students reported being bored with the expository style of the course, its repetitive content and out-of-date case studies that had little if any relevance to their daily lives:

[Civic education] should change the [teaching] method. Do not teach it like in high school, only memorizing laws. I think the lecturers and module developers should be more up to date on current affairs so that the course is not boring. [If] it is just like in junior or senior high school, just theory, then what is it for? (Personal conversation with student\#1)

In some cases, participants felt the civic education course lacked meaning and depth due to a heavy reliance on factual information in order to bring about a form of indoctrination in nationalistic ideologies and policies.

For the existing online tutorial activities, students found the tutorial was uninteresting because the discussions were monotonous (Setiani, 2014). Students said that there was a lack of interaction in the discussions among students, and a lack of attention and response to the discussions from the tutors:

To be honest I was reluctant in joining the online civic education tutorial, because it was monotonous. It was just an individual discussion. (Personal conversation with student\#2)

In my experience, the discussion was not immediately responded to [by the tutor]. I asked a question and it was not answered for more than a week, so it was pointless [to ask questions again]. (Personal conversation with student\#3)

As mentioned earlier, civic education pedagogy is supposed to emphasize knowledge, skills and dispositions, and it is hoped that these aspects also have been covered in the civic education course at UT. However, it seemed that this ideal has not been fully realized yet. Some tutors admitted that most of the civic education modules at UT were only focused on obtaining civic knowledge. It was not easy for tutors to detect and measure civic skills and attitudes in a distance education setting. What could be assessed more readily was students' knowledge of content and skills required as well as attitudes:

So far the demand from civic education has advanced up to the stage of action. [However] we are only able to assess students on their knowledge of the content and skills required as well as their dispositions. (Personal conversation with tutor\#4)

The civic education course was compulsory for all UT students. Therefore, there was a large number of students who participated in the tutorial. For this reason, tutors had concerns about time management with a large number of students in one class (Setiani, 2014):

Our strategy was that we had to check [the online tutorial's website] every day. It was indeed overwhelming. The challenge was how we could manage so it could be efficient and students did not feel neglected. (Personal conversation with tutor\#2) 


\section{The community of inquiry framework}

Based on these findings and our review of the literature, a community of inquiry is proposed as providing a suitable framework for a new revised online civic education course at UT. The community of inquiry framework proposed for the civic education course resonates with a social constructivist view where learning is seen to occur through social, cognitive, and teaching presence.

Social presence refers to "the ability of participants to identify with the group or course of study, communicate purposefully in a trusting environment and develop personal and affective relationships progressively by way of projecting their individual personality" (Garrison, 2011, p. 34). Social presence affords the academic setting for open communication, a sense of belonging to the group and its academic goals. It also supports an environment for learners to express themselves freely and openly, which contributes directly to group cohesion.

Cognitive presence is "the extent to which learners are able to construct and confirm meaning through sustained reflection and discourse in a critical community of inquiry" (Garrison, Anderson, \& Archer, 2001, pp. 10-11). This comprises four phases of critical inquiry, namely the triggering event, exploration, integration, and resolution. The triggering event is the initiation phase of critical inquiry. In this phase, an issue, dilemma, or problem that emerges from the experience is identified or recognized. The second phase is exploration. This phase is characterized by brainstorming, questioning and exchanging information. The third phase is integration. This phase is characterized by constructing meaning from the ideas generated in the exploratory phase. And the fourth phase is a resolution of the dilemma or problem by means of direct action.

Teaching presence refers to "the design, facilitation and direction of cognitive and social processes for the purpose of realizing meaningful and educationally worthwhile learning outcomes" (Garrison et al., 2001, p. 5). As course designers, it is essential for teachers to plan for the structure, process of interaction, and evaluation. Facilitating discourse among students and tutors is critical to "maintaining interest, motivation and engagement of students in effective learning" (Anderson, Rourke, Garrison, \& Archer, 2001, p. 7). As facilitators in online learning, teachers encourage participation of students by modeling, commenting on posts, identifying areas of agreement and disagreement, keeping the discourse focused on learning outcomes, and trying to draw in less active students.

\section{A community of inquiry-based framework}

Civic education should comprise the development of civic dispositions, along with civic knowledge and skills. Civic dispositions include private and public traits of character that are possessed by citizens in a democratic society. These traits include respect for other individuals, willingness to listen, negotiate, and compromise, to develop tolerance, civility and critical mindedness (Branson, 1998). These dispositions can also be introduced and practiced in the online environment of the civic education course. First, the tutors play a valuable role in modeling civic dispositions, guiding students in developing civic virtues and dispositions. Steutel and Spiecker (2004, p. 536) asserted that modeling is understood as a kind of Aristotelian habituation, which is learning by doing virtuous things frequently and consistently under the guidance or authority of a tutor. Civic skills emphasize civility through 
collaborative, reflective, and respectful engagement leading to the development of tolerance and understanding of diverse perspectives. Tolerance is defined by Moore and Walker (2011) as:

[An] acceptance of and respect for people with different values, beliefs and cultural backgrounds than one's own accompanied by a willingness to allow others to maintain and express their values, beliefs and culture. A person practicing tolerance will show empathy for others and a diminished response to their differences. (p. 51)

Tolerance requires respect and recognition (Jackson \& Bahrissalim, 2007). Respect refers to being patient with differences, appreciating differences, and appreciating being different (Raihani, 2011). In education, Peters (1966) described the meaning of respect as the "awareness one has that each man [sic] has his own aspirations, his own viewpoint on the world; that each man takes pride in his achievements, however idiosyncratic they may be" (p. 34). This would imply that students are taught to listen to what others have to say, to accept personal differences, to be considerate and not to ignore others' needs (Sanderse, 2013). Tolerance is an important virtue in a multicultural society (Comte-Sponville, 2001; Willems, Denessen, Hermans, \& Vermeer, 2012). The process of modeling civic dispositions in the online civic education course begins with tutors modeling tolerance and respect for students as they facilitate the discussion activities. They greet the students, express appreciation for their ideas, and show respect for their opinions, whether or not they agree with them. If they disagree and want to challenge students on their ideas and practice, they do so in a respectful manner, being mindfully aware of their own emotional reactions. Tutors who model respect will always appreciate each individual student.

The students can also show their respect of their fellow students by using polite language when responding to other students' comments, referring to names when responding, acknowledging other students' ideas, expressing appreciation, while being critically respectful. In the online civic education tutorial students will have different backgrounds, social and economic status, and represent different cultures and religions. Therefore, when they collaborate and engage in discussion, it is essential that they have tolerance for each other, especially if they have different opinions or points of view about the topics being discussed. The students may have different opinions, and they may be passionate about those opinions, but they may also need to find compromise and solutions without conflict. To produce that kind of environment the tutors and the students would need to have some kind of assurance before the tutorial begins, an understanding that they will contribute to creating a class environment that enables everyone to express their voice openly and safely. Such interaction is expected in a democratic society.

There will likely be times when disagreement and emotions are strongly held. We should learn to recognize these as opportunities for growth in civic knowledge, skills, and dispositions rather than as disruptions to the democratic/civic processes. So rather than trying to squelch or suppress these emotions and occurrences, tutors would be encouraged and trained to work with students in negotiating and mediating understandings that would develop the civic climate in the tutorial. These are the foundations upon which our proposed new model for civic education at UT is based, the critical attributes of which are further explored in the remainder of this paper. 


\section{Social presence}

Students in a distance learning program may experience isolation and alienation from the institution because of their physical separation from instructors and other students (Garrison et al., 2001; Morgan \& Tam, 1999; Rovai, 2007). Development of feelings of social presence can assist, reduce or eliminate these outcomes (Rovai, 2007). Research evidence suggested that social presence among members of a learning community increased discourse, facilitated critical thinking carried on by the community of learners, strengthened a sense of community, promoted learner satisfaction, facilitated collaborative learning, and contributed to the success of the learning experience (Garrison \& Anderson, 2003; Gunawardena \& Zittle, 1997).

In regard to creating a community within the class and implementing the model, we suggest that it is necessary for students in the online civic education tutorial to be divided into several groups per class. Each group should consist of 10 to 15 students; thus, each class would have about 20 to 30 groups. Dividing students into smaller groups in online discussions is important for supporting critical and reflective thinking skills. Research findings showed that there is a significant positive correlation between group size and the frequency of "higher level knowledge occurrences" (Hew \& Cheung, 2012). This research result suggests that groups of about 10 students is an optimum size for discussion groups that achieve higher levels of discourse and deeper level learning (Hew \& Cheung, 2012). Nonnecke and Preece (2000) also suggested that larger group size may diminish the need for any given group member to contribute and could invoke unnecessary demands on the students (Schellens \& Valcke, 2006) as they would need to deal with large quantities of postings.

The syllabus for the tutorial should be prepared in a way that it encourages the establishment of social presence in the first week of the online tutorial activities. Tutors should welcome students to the tutorial and post an introductory message that includes a personalized mini-biography-introduction, a plan of the tutorial activities during the 8-week period, information about the learning outcomes of the course, and encouragement for the students to collaborate in the discussion activities. Rovai (2007) also suggested instructors need to access the discussion forums every day, not only to keep up with the conversations, but to indicate to participants that their postings are being read and to stimulate in-depth reflective discussions and hold students responsible for their thinking.

\section{Cognitive presence}

In the discussion forums of the online civic education tutorial, the students are expected to have active discussions in which they can collaboratively construct understanding based on their experiences and their background. This collaborative construction of knowledge applies to the development of civic knowledge, civic skills, and civic dispositions. In the sections that follow, the underlying assumption is that the tutorial and its activities are based on this comprehensive, constructivist approach in which knowledge, skills, and dispositions are developed through curricular and pedagogical approaches that allow for such development.

The activities in the online civic education course would begin with initiations. Usually, initiations in the online civic education tutorial at UT consist of the reading materials. The materials could be taken from the summaries of the modules of the 
civic education course and from other sources, such as journals, books or the Internet. The reading materials in the online civic education tutorial basically provide the students additional sources to assist them with comprehending the materials of the course. Students can upload reading materials and videos as well, so the tutor can invite students to share materials that relate to topics of the week.

The discussion forum in the civic education tutorial should be a place where students have interactions with their tutor and fellow students. In this forum, students are expected to have active, meaningful discussions with other students. Some students commented in the interview that the case studies provided in the tutorial were out of date; thus, they were not interested in being involved in the discussions. To have an active discussion, tutors need to provide interesting topics that invite the students' own opinions and justifications. Interesting cases for discussion are likely to connect to current events in society, or which reflect real-life problems the students are likely to have some experience or connection with (Chan, 2010).

Most of the UT students are working adults. According to the work of Knowles, Holton, and Swanson (2011), adult learners are more interested in learning when the learning materials are relevant to their experiences and their lives. Furthermore, adult learners prefer cases that are presented in realistic and contemporary life contexts (Knowles et al., 2011).

Developing contemporary case studies in the online civic education tutorial would not only engage students, but help them become aware of current situations and conditions in the nation, drawing their attention more effectively in the tutorial and inviting their involvement in the discussion forums. As students share their thoughts and experiences with others in the forum, they also develop critical thinking by discussing the cases from their own perspectives and offering sometimes alternative solutions to the problems. But Indonesian students are not used to thinking critically about civic issues, nor are they familiar with courses that ask them to do anything but memorize information and practice skills, least of all speak against the current organization, as was evident in our investigation of students and tutors' attitudes and understandings about the current online experience in the course.

Cognitive presence is "the extent to which learners are able to construct and confirm meaning through sustained reflection and discourse in a critical community of inquiry" (Garrison et al., 2001, pp. 10-11). This model consists of four phases of practical inquiry: triggering event, exploration, integration, and resolution.

A triggering event in an online discussion is a well-thought-out topic or case that would ensure full engagement from the students and tutor (Garrison, 2011). The case study or topic of the discussion should speak to an issue or concept being studied in that week. The tutors are responsible for initiating this phase; however, the students could also provide the issues and problems as they relate to their experiences. Direct personal experience is crucial to empowerment (Herman, 1996). According to Garrison (2011), students should be involved in assessing the state of knowledge, generating unintended but constructive ideas and taking active roles in the learning experiences. Tutors should share control with students over the discussion topics so that students can "own their learning" and actively participate in the discussions. It is important for tutors and students in the online tutorial to incorporate their own discussion questions and avoid questions that can be answered simplistically in one or two words, or have one right answer as a way of stimulating critical thinking (Hosler \& Arend, 2013). 
The triggering event needs to invite curiosity, elicit interest and encourage different perspectives. Good questions derived from relevant content can trigger thoughtful investigations. For instance, the questions could begin with queries such as, "Why do you think such and such is?" or "What are the consequences?" (Hosler \& Arend, 2013). Bender (2003) suggested that instructors should create questions that support the students in making comparisons, highlighting contrasts, or making predications, such as, "What do you think will happen if ...?" (p. 153).

After the topic or case study is established each week, the next step is exploration. This involves investigating the issue or problem and searching for relevant information and possible explanations (Garrison, 2011). This activity would be done collaboratively in each tutorial group, with students searching information, sharing and exploring ideas, soliciting relevant perspectives or experiences and eliciting comments from various sources.

The integration phase involves constructing a meaningful solution or exploration (Garrison, 2011) in which students integrate information and ideas, offer agreement or disagreement, build on each other's ideas, and provide a rationale and justification for a solution. Students are thus engaged in a critical discourse that will shape their understanding (Garrison, 2011).

The fourth phase is the resolution of the problem. The culture and dialogue of the classroom should encourage students not only to examine problems from different perspectives, but to relate questions to their own values and sensibilities of social justice, equality, respect and consideration, to be open to and considerate of other people, and to be able to express a different opinion if needed. Students should be able to practice communicating and working cooperatively with other students in discussion forums in a critical fashion.

\section{Teaching presence}

Garrison (2011) reported that it was not easy to design and organize an online learning course of studies, but more demanding than face-to-face teaching. Teachers may provide links to sites that may provide additional material that is relevant to the subject. The role of teaching also can be assumed by students vis-à-vis their engagement in online discussions, which can also be seen as the sharing of power among students and tutors. Giving students the opportunity to be a peer facilitator would help the tutors better manage the discussions. Students in each group of the online tutorial could be asked to take turns as peer moderators at weekly discussions. Other students in the group could also have an opportunity to take an active role in the learning process and voice their opinions in the discussions. With this arrangement, teachers and learners have important, complementary responsibilities; they both are part of the process of learning (Garrison, 2011).

\section{Conclusion}

We have argued that civic education should include not only civic knowledge, but also civic skills and civic dispositions, that it is important to provide a comprehensive approach to the development of citizenship, and that this can be done, we think, in an online tutorial. The community of inquiry framework and a democratic pedagogy would be expected to develop civic knowledge, skills, and dispositions in more effective ways. The notion of the model in the civic education course ought to 
allow tutors to model the civic knowledge, skills, and dispositions, while encouraging students to engage in the course. This model for the online tutorial would liberate, empower and help students to find their voice in their learning and civic dispositions.

We also argued that such a rekindling of the online tutorial would be especially desirable in the developing of democracy in Indonesia, with its multitudinous and diverse population, and its multiplicity of languages, cultures and religious affiliations. Any opportunity for people to learn about the experiences, needs and aspirations of others comprising their nation and brotherhood should be welcomed and supported. Moving this agenda forward will involve many challenges, not the least of which is the dominant teacher-centered approach to education prevalent within institutions of learning throughout the Indonesian society and the passivity this promotes among students and tutors alike. This is an important consideration for any design to reform educational practices in Indonesia, just as it would be in any society. One of the considerations for the implementation, and equally challenging to the reformulation of the tutorial generally, will be how to engage the tutors and representative students in putting these ideas into practice, so as to encourage people to engage in the initiative.

In our empirical research, we found good reason to redesign the civic education course at UT. In our literature review and analysis we found a promising set of ideas and a model for developing a pedagogy and type of online experience in the civic education tutorial at UT that is consistent with the goals and teachings of the civic education course and imminently beneficial to the nation. The next logical step in our quest is to implement this new and revised model of civic education and evaluate its impacts on learning and teaching outcomes at UT.

\section{Disclosure statement}

No potential conflict of interest was reported by the authors.

\section{Notes on contributors}

Made Yudhi Setiani is a lecturer in the Government Science Study Program, at Universitas Terbuka. One of her main responsibilities is conducting online tutorial for several courses in her Study Program. Her research interests include political participation, political education, and distance education.

Allan M. MacKinnon is an Associate Professor in the Faculty of Education at Simon Fraser University. His research interests lie in the areas of science and environmental education, teacher education and international development.

\section{References}

Anderson, T., Rourke, L., Garrison, D. R., \& Archer, W. (2001). Assessing teaching presence in a computer conferencing context. Journal of Asynchronous Learning Networks, 5(2), 1-17. Retrieved from http://onlinelearningconsortium.org

Andriani, D. (2013). Online tutorial for ODL students: Sharing experience from philosophy of science course offered at department of education Universitas Terbuka. Jurnal Pendidikan Terbuka dan Jarak Jauh, 14, 13-23. Retrieved from http://jurnal.ut.ac.id/ JPTJJ/

Bender, T. (2003). Discussion-based online teaching to enhance student learning: Theory, practice, assessment. Sterling, VA: Stylus. 
Branson, M. S. (1998). The role of civic education: A forthcoming education policy task force position paper for the communitarian network. Washington, DC: The Communitarian Network. Retrieved from http://www.civiced.org/papers/articles role.html

Chan, S. (2010). Designing an online class using a constructivist approach. Journal of Adult Education, 39, 26-39. Retrieved from https://www.mpaea.org/?page=publications

Cogan, J. J. (1998). Citizenship for the 21st century: An international perspective on education. London: Kogan Page.

Comte-Sponville, A. (2001). A small treatise on the great virtues. New York, NY: Holt.

Dynneson, T. (1992). What's hot and What's not in effective citizenship instruction. The Social Studies, 83, 197-200. doi:10.1080/00377996.1992.9956232

Freire, P. (2000). Pedagogy of the oppressed. New York, NY: Continuum.

Garrison, D. R. (2011). E-Learning in the 21st century: A framework for research and practice. New York, NY: Routledge.

Garrison, D. R., \& Anderson, T. (2003). E-Learning in the 21st century: A framework for research and practice. New York, NY: RoutledgeFalmer.

Garrison, D. R., Anderson, T., \& Archer, W. (2000). Critical inquiry in a text-based environment: Computer conferencing in higher education. The Internet and Higher Education, 2, 87-105. doi:10.1016/S1096-7516(00)00016-6

Garrison, D. R., Anderson, T., \& Archer, W. (2001). Critical thinking, cognitive presence, and computer conferencing in distance education. American Journal of Distance Education, 15, 7-23. doi:10.1080/08923640109527071

Gerzon, M. (1997). Teaching democracy by doing it! Educational Leadership, 54, 6-11. Retrieved from http://www.ascd.org/publications/educational-leadership/feb97/vol54/ num05/Teaching-Democracy-by-Doing-It!.aspx

Gunawardena, C., \& Zittle, F. (1997). Social presence as a predictor of satisfaction within a computer mediated conferencing environment. American Journal of Distance Education, 11, 8-26. doi:10.1080/08923649709526970

Hahn, C. (1998). Becoming political: Comparative perspectives on citizenship education. Albany: State University of New York Press.

Herman, L. (1996). Personal empowerment. In T. L. Becker \& R. A. Couto (Eds.), Teaching democracy by being democratic (pp. 53-74). Wesport, CT: Praeger.

Hew, K. F., \& Cheung, W. S. (2012). Student participation in online discussions: Challenges, solutions, and future research. New York, NY: Springer.

Hosler, K. A. \& Arend, B. D. (2013). Strategies and principles to develop cognitive presence in online discussions. In Z. Akyol \& D. R. Garrison (Eds.), Educational communities of inquiry: Theoretical framework, research, and practice (pp. 148-167). Hershey, PA: Information Science Reference.

Jackson, E., \& Bahrissalim (2007). Crafting a new democracy: Civic education in Indonesian Islamic universities. Asia Pacific Journal of Education, 27, 41-54. doi:10.1080/02188790 601142892

Kalidjernih, F. K. (2005). Post-colonial civic education: A critical study of production and reproduction of the Indonesian civic ideal (Unpublished doctoral dissertation). Hobart: University of Tasmania.

Knowles, M. S., Holton, E. G., \& Swanson, R. A. (2011). The adult learner: The definitive classic in adult education and human resource development (7th ed.). Boston, MA: Elsevier, Butterworth-Heinemann.

Mattern, M. (1997). Teaching democratic theory democratically. PS: Political Science \& Politics, 30, 510-515. doi:10.2307/420133

Mikhael, M. B., Sihotang, K., Sutrisno, Soegito, A. Y., \& Heru, A. M. (2011). Civic education: Upaya mengembalikan episteme politik [Civic education: Efforts to restore political episteme]. Jakarta: Fidei Press.

Moore, H. K., \& Walker, C. A. (2011). Tolerance: A concept analysis. Journal of Theory Construction \& Testing, 15, 48-52. Retrieved from http://tuckerpub.com/jtct.htm

Morgan, C. K., \& Tam, M. (1999). Unravelling the complexities of distance education student attrition. Distance Education, 20, 96-108. doi:10.1080/0158791990200108

Nonnecke, B., \& Preece, J. (2000). Lurker demographics: Counting the silence. In T. Turner, G. Szwillus, M. Czerwinski, F. Peterno, \& S. Pemberton (Eds.) Proceedings of the ACM CHI 2000 Conference on Human Factors in Computing Systems, (pp. 73-80). The 
Hague: IEEE Computer Society. Retrieved from http://www.cis.uoguelph.ca/\%7Enon necke/research/demographics.pdf

Patrick, J., \& Hoge, J. (1991). Teaching government, civics, and the law. In J. Shaver (Ed.), Handbook of research on social studies teaching and learning (pp. 427-436). New York, NY: Macmillan.

Peters, R. S. (1966). Ethics and education. London: Allen \& Unwin.

Print, M., Ornstrom, S., \& Skovgaard Nielsen, H. S. (2002). Education for democratic processes in schools and classrooms. European Journal of Education, 37, 193-210. doi:10.1111/1467-3435.00102

Print, M., \& Smith, A. (2000). Teaching civic education for a civil, democratic society. Asia Pacific Education Review, 1, 101-109. doi:10.1007/BF03026150

Raihani. (2011). A whole-school approach: A proposal for education for tolerance in Indonesia. Theory and Research in Education, 9, 23-39. doi:10.1177/1477878510394806

Rovai, A. P. (2007). Facilitating online discussions effectively. The Internet and Higher Education, 10, 77-88. doi:10.1016/j.iheduc.2006.10.001

Sanderse, W. (2013). The meaning of role modelling in moral and character education. Journal of Moral Education, 42, 28-42. doi:10.1080/03057240.2012.690727

Schellens, T., \& Valcke, M. (2006). Fostering knowledge construction in university students through asynchronous discussion groups. Computers \& Education, 46, 349-370. doi:10.1016/S0360-1315(06)00021-2

Sears, A. (1994). Social studies as citizenship education in English Canada: A review of research. Theory and Research in Social Education, 22, 6-43. doi:10.1080/00933104. 1994.10505714

Setiani, M. Y. (2014). A social constructivist learning approach for an online civic education tutorial at the Indonesia Open University (Unpublished doctoral dissertation). Burnaby, British Columbia: Simon Fraser University.

Soder, R. (1996). Teaching the teachers of the people. In R. Soder (Ed.), Democracy, education and the schools (pp. 244-274). San Francisco, CA: Jossey-Bass.

Steutel, J., \& Spiecker, B. (2004). Cultivating sentimental dispositions through Aristotelian habituation. Journal of Philosophy of Education, 38, 531-549. doi:10.1111/j.03098249.2004.00403.x

Wahab, A. A., \& Sapriya (2011). Teori dan landasan pendidikan kewarganegaraan [Theories and foundations of civic education]. Bandung: Alfabeta.

Willems, F., Denessen, E., Hermans, C., \& Vermeer, P. (2012). Students' perceptions and teachers' self-ratings of modelling civic virtues: An exploratory empirical study in Dutch primary schools. Journal of Moral Education, 41, 99-115. doi:10.1080/03057240.2011. 615827

Zuriah, N. (2011). Model pengembangan pendidikan kewarganegaraan multikultural berbasis kearifan lokal dalam fenomena sosial pasca reformasi di perguruan tinggi [Development model of multicultural civic education based on local wisdom in social phenomenon in post reform in higher education]. Jurnal Penelitian Pendidikan, 12, 75-86. Retrieved from http://jurnal.upi.edu/penelitian-pendidikan 